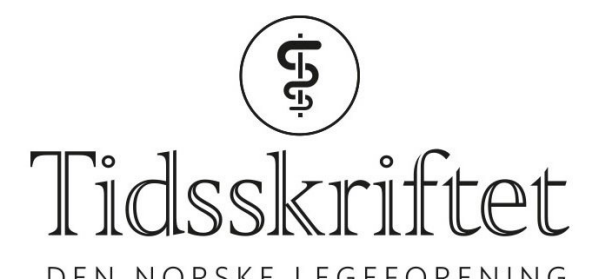

DEN NORSKE LEGEFORENING

\title{
Aneurismer i koronararterier
}

KORT KASUISTIKK

\section{JENS VIKSE}

E-post: jensvikse@gmail.com

Seksjon for klinisk immunologi

Stavanger universitetssjukehus

Jens Vikse er lege i spesialisering i revmatologi.

Forfatter har fylt ut ICMJE-skjemaet og oppgir ingen interessekonflikter.

\section{CHARLOTTE SALAND}

Kardiologisk avdeling

Stavanger universitetssjukehus

Charlotte Sæland er lege i spesialisering i indremedisin og under grenspesialisering $\mathrm{i}$

hjertesykdommer.

Forfatter har fylt ut ICMJE-skjemaet og oppgir ingen interessekonflikter.

\section{CHRISTER OGNE}

Kardiologisk avdeling

Stavanger universitetssjukehus

Christer Ogne er overlege og spesialist i indremedisin og i hjertesykdommer.

Forfatter har fylt ut ICMJE-skjemaet og oppgir ingen interessekonflikter.

\section{OLE JACOB GREVE}

Avdeling for radiologi

Stavanger universitetssjukehus

Ole Jacob Greve er seksjonsoverlege og spesialist i radiologi og i nukleærmedisin.

Forfatter har fylt ut ICMJE-skjemaet og oppgir ingen interessekonflikter.

\section{SVEIN JOAR AUGLAED JOHNSEN}

Seksjon for klinisk immunologi

Stavanger universitetssjukehus

Svein Joar Auglænd Johnsen er ph.d., overlege, spesialist i indremedisin og er under spesialisering i revmatologi.

Forfatter har fylt ut ICMJE-skjemaet og oppgir ingen interessekonflikter.

Koronararterieaneurismer kan oppstå som følge av blant annet aterosklerose og enkelte revmatiske sykdommer. Her presenteres en mann med høy kardiovaskulær risikoprofil, STelevasjonsinfarkt og funn av aneurismer i flere koronararterier.

En etnisk norsk mann i 6o-årene med hypertensjon, dyslipidemi, betydelig røykeanamnese og tidligere iskemisk hjerneinfarkt gjennomgikk en prehospital hjertestans med ventrikkelflimmer som første registrerte hjerterytme. Han ble resuscitert og brakt til koronarangiografi. EKG etter resuscitering var forenlig med ST-elevasjonsinfarkt i nedre vegg. Ved undersøkelsen fant man trombotisk okklusjon i midtre avsnitt av høyre 
koronararterie samt spredte aterosklerotiske forandringer i både høyre og venstre koronararterie. I tillegg hadde pasienten flere aneurismer i alle tre koronarkar (figur 1).

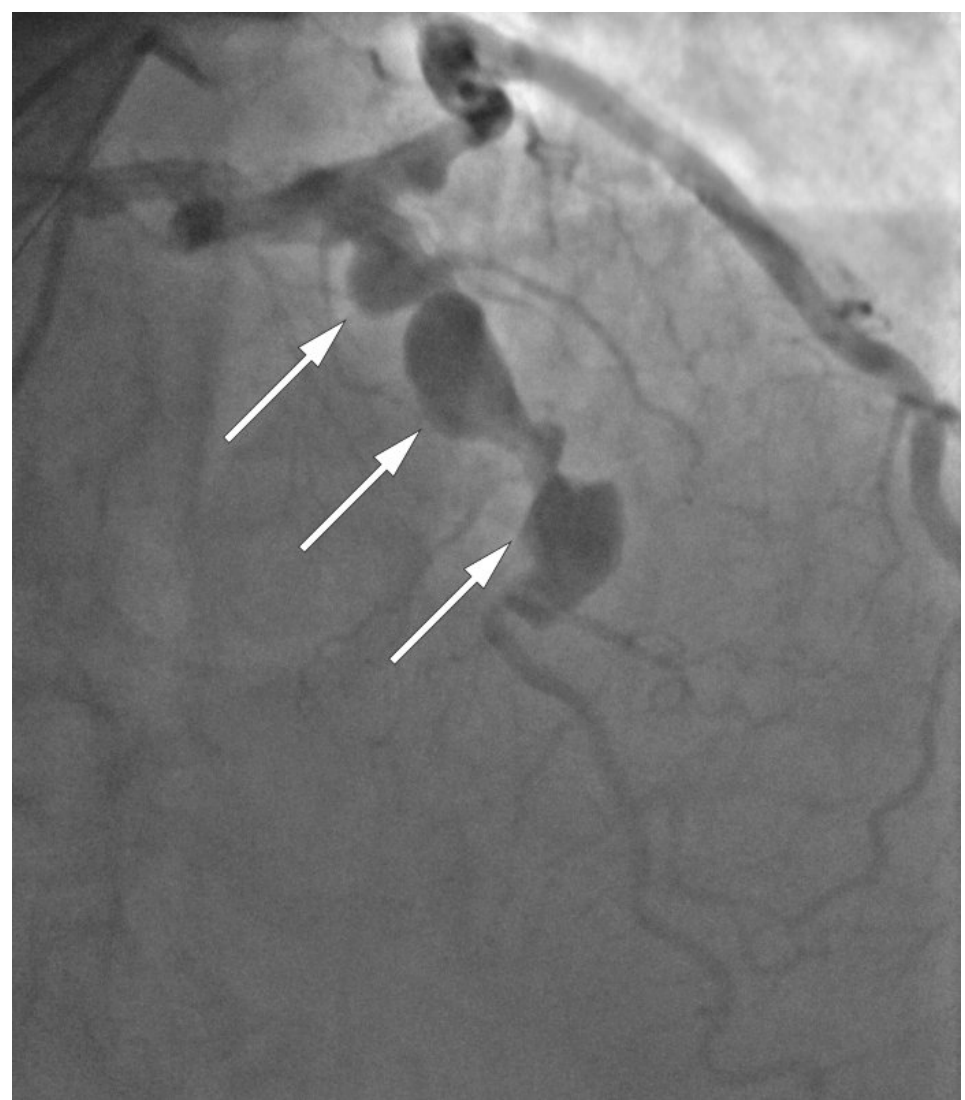

Figur 1 Koronarangiografi av venstre koronararterie. Det ses flere aneurismer i venstre fremre nedadstigende arterie (piler).

Pasientens trombotiske koronarokklusjon ble revaskularisert med perkutan koronar intervensjon, og det ble startet sekundærprofylaktisk behandling for å redusere risikoen for fremtidige koronare hendelser. Som ledd i videre utredning ble det gjennomført CT aortografi med følgende funn: Ektasi av aorta ascendens, med største diameter $43 \mathrm{~mm}$ i nivå med truncus pulmonalis, et infrarenalt abdominalt aortaaneurisme med største diameter $32 \mathrm{~mm}$, samt ektasi av arteria iliaca communis bilateralt (figur 2). CT-funnene ga ikke indikasjon for intervensjon, og det ble avtalt oppfølging ved kardiologisk og karkirurgisk avdeling for kontroll av henholdsvis koronarsykdom og aortaaneurismer. 


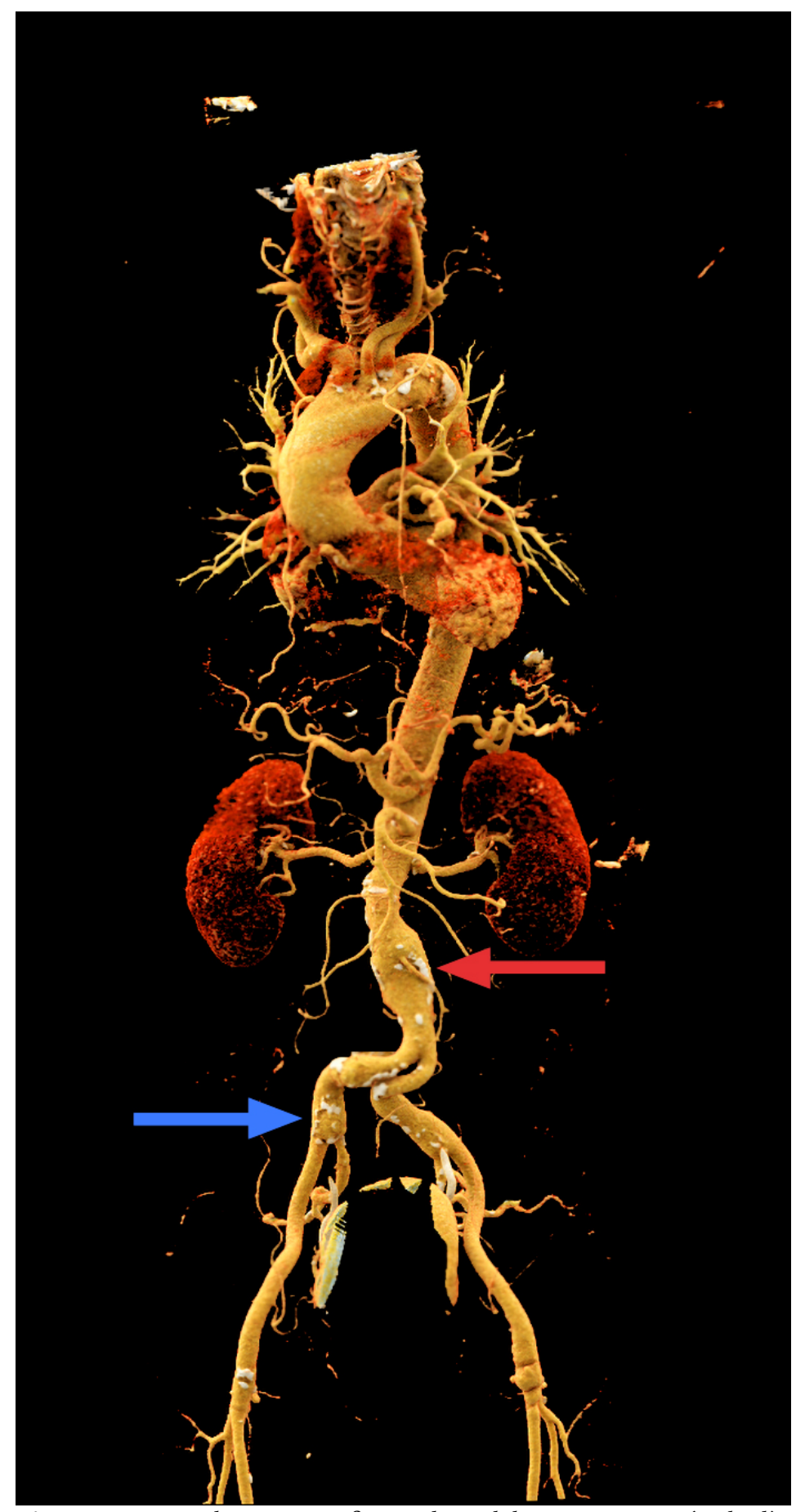

Figur 2 Aorta med utposing infrarenalt med diameter $32 \mathrm{~mm}$ (rød pil) samt ektasi av arteria iliaca communis bilateralt (blå pil).

\section{Diskusjon}

Aneurismer er et resultat av svakhet i åreveggen med påfølgende dilatasjon (1). Observert forekomst av koronararterieaneurismer hos pasienter som gjennomgår koronarangiografi er 0,3-5,3\% (1, 2). Høyre koronararterie er oftest affisert (40 \%), etterfulgt av venstre fremre nedadstigende arterie (32 \%) (2). Aneurismer kan gi komplikasjoner i form av intraaneurismal trombosedanning med eller uten distal embolisering, kompresjon av omkringliggende strukturer og i sjeldne tilfeller aneurismeruptur (2). Aneurismer i nær relasjon til koronare stenoser kan være en utfordring ved perkutan koronar intervensjon, da de anatomiske forholdene kan vanskeliggjøre stentimplantasjon (2). Den vanligste årsaken til både koronar- og aortaaneurismer er aterosklerose, som er assosiert med om lag halvparten av koronararterieaneurismer hos voksne (1). Revmatiske og genetiske årsaker representerer mer sjeldne differensialdiagnoser (1).

En viktig årsak til ikke-aterosklerotiske koronararterieaneurismer er Kawasakis syndrom, 
en vaskulittsykdom som kjennetegnes av feber, konjunktivitt, mukokutane lesjoner og cervikal lymfadenopati (3). Sykdommen rammer oftest barn under fem år, men kan også debutere i voksen alder (4). Om lag $25 \%$ av ubehandlede pasienter utvikler koronare aneurismer (5), og i sjeldne tilfeller kan det også ses aneurismer i aorta og andre ikkekoronare arterier (6).

Systemiske vaskulittsykdommer som kan gi tilsvarende koronar- og aortaaffeksjon er kjempecellearteritt, Takayasus arteritt, ANCA-assosierte vaskulitter, polyarteritis nodosa og Behçets sykdom $(1,7)$. Andre revmatiske sykdommer som systemisk lupus erythematosus og revmatoid artritt kan også føre til koronare aneurismer $(1,7)$. Infeksiøse årsaker til mykotiske aneurismer inkluderer hiv, syfilis og borreliose (8). Ikke-inflammatoriske differensialdiagnoser er genetiske bindevevssykdommer som vaskulær Ehlers-Danlos' syndrom, Marfans syndrom og Loeys-Dietz' syndrom, samt fibromuskulær dysplasi og medfødte aneurismer $(1,7)$. Aneurismer kan også oppstå som komplikasjon etter perkutan koronar intervensjon (2).

Vår pasient hadde ingen symptomer eller funn som ga mistanke om Kawasakis syndrom. Det var ingen kliniske, biokjemiske eller immunserologiske holdepunkt for vaskulitt eller annen revmatisk sykdom, og det var ingen risikofaktorer eller ekstravaskulære manifestasjoner som skulle tilsi nevnte infeksiøse eller genetiske tilstander. Sekvele etter udiagnostisert Kawasakis syndrom i tidligere leveår kunne ikke utelukkes, men i lys av pasientens betydelige kardiovaskulære risikoprofil ble aterosklerose vurdert som mest sannsynlige årsak.

American Heart Association har publisert retningslinjer for behandling av Kawasakis syndrom, inkludert ledsagende koronararterieaneurismer (5). Derimot finnes ingen etablerte retningslinjer for behandling av koronararterieaneurismer assosiert med aterosklerotisk koronarsykdom (2). Signifikant koronarsykdom behandles med sekundærprofylakse med eller uten revaskularisering (2). Som nevnt kan koronararterieaneurismer vanskeliggjøre stentimplantasjon, og pasienter med STelevasjonsinfarkt som får stentimplantasjon i en okkludert aneurismal koronararterie, har $\emptyset \mathrm{kt}$ mortalitet og høyere forekomst av stenttrombose (2). Kirurgisk intervensjon er anbefalt ved aneurisme i venstre hovedstamme og hos pasienter med flere aneurismer over $20 \mathrm{~mm} \mathrm{i}$ diameter (2). Andre behandlingstiltak inkluderer coilembolisering og trombektomi, men fremtidige studier kreves for å utforme retningslinjer for slik behandling (2). For tilfeldig påviste aneurismer hos pasienter med koeksisterende aterosklerose uten invasivt behandlingstrengende stenoser anbefales aggressiv antiaterosklerotisk behandling og kontroll av risikofaktorer (2). Indikasjonen for, og eventuell varigheten av, dobbel platehemming og/eller antikoagulasjon er omdiskutert (2).

\section{LITTERATUR:}

1. Abou Sherif S, Ozden Tok O, Taşköylü Ö et al. Coronary artery aneurysms: A review of the epidemiology, pathophysiology, diagnosis, and treatment. Front Cardiovasc Med 2017; 4: 24. [PubMed][CrossRef]

2. Kawsara A, Núñez Gil IJ, Alqahtani F et al. Management of coronary artery aneurysms. JACC Cardiovasc Interv 2018; 11: 1211-23. [PubMed][CrossRef]

3. Burns JC, Glodé MP. Kawasaki syndrome. Lancet 2004; 364: 533-44. [PubMed][CrossRef]

4. Gomard-Mennesson E, Landron C, Dauphin C et al. Kawasaki disease in adults: report of 10 cases. Medicine (Baltimore) 2010; 89: 149-58. [PubMed][CrossRef]

5. McCrindle BW, Rowley AH, Newburger JW et al. Diagnosis, treatment, and long-term management of Kawasaki disease: A scientific statement for health professionals from the american heart association. Circulation 2017; 135: e927-99. [PubMed][CrossRef]

6. Hoshino S, Tsuda E, Yamada O. Characteristics and fate of systemic artery aneurysm after Kawasaki disease. J Pediatr 2015; 167: 108-12.e2. [PubMed][CrossRef] 
7. Díaz-Zamudio M, Bacilio-Pérez U, Herrera-Zarza MC et al. Coronary artery aneurysms and ectasia: role of coronary CT angiography. Radiographics 2009; 29: 1939-54. [PubMed][CrossRef]

8. Jiang LC, Cao JY, Chen M. Coronary artery aneurysm combined with other multiple aneurysms at multiple locations: A case report and systematic review. Medicine (Baltimore) 2017; 96: eg230.

[PubMed][CrossRef]

Publisert: 28. januar 2019. Tidsskr Nor Legeforen. DOI:10.4045/tidsskr.18.0325

Mottatt 13.4.2018, første revisjon innsendt 29.8.2018, godkjent 10.10.2018.

(C) Tidsskrift for Den norske legeforening 2020. Lastet ned fra tidsskriftet.no 